\title{
影响天气预报准确率的因素及对策分析
}

\author{
李丹 ${ }^{1}$ 㚞希彬 $^{2}$ 辛金 $^{1}$ 朱智华 $^{1}$ 徐金秀 $^{1}$ \\ 1 东港市气象局 2 丹东市气象局 \\ DOI:10.32629/eep.v3i7.904
}

\begin{abstract}
[摘 要] 随着国家实力不断增强,各行各业都得到了全面发展, 在气象预报行业中, 对气象进行预测和预 报,可以使人们对某一区域内未来一段时间内的天气变化进行掌握和了解。对天气预报工作来说, 影响因 素有很多, 这也使得天气预报工作具有一定的复杂性和不确定性。由于社会经济不断发展, 人们生活水平 和质量也在不断提高,人民群众对天气预报的要求也越来越高,所以相关部门需要提高对天气预报准确 性的重视, 满足人们日常生活工作的实际需求。本文主要研究影响天气预报准确性的因素,结合实际问题 提出解决对策,希望对天气预报准确性的提高具有积极作用。
\end{abstract}

[关键词] 天气预报; 准确性; 因素

中图分类号：P429 文献标识码：B

天气预报是气象工作中的主要部 分, 以当地实际气象观测数据为基础, 根据数值预报模式进行分析, 满足公众 气象服务需求, 为人们的出行和生活提 供方便。预报预警产品包括中短期天气 预报、气候分析、大气成分、农业气候、 预测评估等相关业务。天气预报是现阶 段我国气象工作的重点, 气象局负责的 主要工作内容就是将当地天气预报、重 要天气报告、预警信号等数据进行及时 播报, 为政府机构和人民群众提供良好 气象服务。

\section{1 影响天气预报准确性的因素}

天气预报工作靠的是预报工作人员 的综合判断和分析, 结合气象观测方法 和数值天气预报, 是一门较为综合的学 科。天气预报工作的不同阶段都存在不 确定性, 所以预测结果和实际天气情况 也会存在一定偏差。天气预报工作存在 技术问题, 主要的问题包括以下几点:

\section{1 数据信息不够全面}

气象站分为国家气象站和区域气象 站, 主要工作任务就是积累准确性、具有 可比性和代表性的气候观测数据, 确保 数据信息的稳定可靠。时间观测方面, 对天气数据信息进行监测时, 获取到连 续的气象数据。虽然城市天气监测站分 布逐渐变得密集, 但是空间间隔仍然存
在。如果在某段时间或是空间间隔内天 气发生变化, 那么获取到的监测信息也 缺乏完整性, 天气预报测量精确度也会 受到影响 ${ }^{[1]}$ 。

\section{2 天气预报缺乏精细性}

天气预报工作主要是利用大气运动 规律来获取气象数据信息, 通过对数字 知识和物理知识进行综合分析, 分析技 术依赖于数学的发展, 而数学的发展又 会对其产生制约, 进而得出结论。一般情 况下, 业务人员需要及时校准数据信息, 结合各种各样的预测技术和诊断手段, 对天气进行预报, 进而发布天气预报产 品。在具体预测过程中, 观测和预测之间 有着不可分割的紧密联系, 所以说, 观测 人员的实际操作能力需要有较高水平, 这样才能确保观测结果的准确性, 但是 人为操作毕竟存在一定误差, 因此, 现阶 段天气预报也缺少精细性。

\section{3观测环境具有局限性}

在我国气象法的规定中, 要求气象 观测站必须建立在视野开阔的开放地 区, 周围不可以有高层建筑, 否则会影 响观测效果。但是由于城市现代化发展 较快, 以及其他影响因素, 近几年城市 建设规模也在增大, 各地网络发展都很 快, 气象观测环境受到影响的同时观测 设施也受到了破坏。影响天气预报准确
性的原因也包括气象观测站观测数据 信息的代表性和连续性, 如果气象观测 环境受到影响, 那么天气预报也会失去 部分准确性 ${ }^{[2]}$ 。

1. 4预报人员缺乏专业素养

对于天气预报工作来说, 基层台站 预报人员的专业水平直接决定着天气预 报工作质量, 对预报工作的准确性也有 着影响。气象工作站的工作比较辛苦, 工作环境也较为恶劣, 对工作人员的素 质要求也较高, 但是目前来说, 很多地区 的气象预报工作人员都缺乏基本的专业 素质, 实际操作能力也有所欠缺。现代化 新型预报技术虽然可以对天气状进行精 确及时的预测, 但是工作人员的工作能 力如果无法达到标准, 业务能力也不够 良好, 对现代化信息技术的掌握程度不 足, 这些原因都会导致天气预报工作受 到影响, 缺乏足够的准确率。这种现象在 很多气象部门都有存在, 预报人员的专 业素质达不到标准, 对天气预报行业的 未来发展也会产生阻碍 ${ }^{[3]}$ 。

\section{2 提高天气预报准确性的对策}

2. 1 提高观测能力

天气预报准确性的提高和观测站的 观测能力和水平有着紧密联系, 首先, 提 高气象防灾减灾能力, 加强气候变化和 资源开发利用的基础, 进而对天气预报 
的准确性进行提高。天气预报准确性的 提高需要提升专业水平, 不断建设和完 善观测系统, 加快气象观测的自动化, 同 时加强观测系统标准化, 使气象观测系 统在天气预报工作中可以充分发挥作用 和价值。其次, 提升气象工作预防灾害能 力, 不管是一般性天气还是灾害性天气 过程, 甚至是过渡天气, 都需要进行全面 及时的监测。观测数据信息需要得到改 进和充分利用, 通过对其进行质量控制, 不断提高数据信息质量监测水平, 完善 气象服务系统, 对观测数据信息进行深 化, 促进数据产品的进一步应用 ${ }^{[4]}$ 。

\section{2 完善短期和临近天气预警系统}

近些年, 由于环境的污染和破坏, 全 球变暖问题日益严重, 在此背景下, 极端 天气发生概率也在提高。要想有效提高 天气预报水平, 就需要提高对气象监测 点的建设, 气象灾害的综合监测水平也 需要得到提高, 加强对未来极端天气预 报的能力, 同时要做好总结, 判断未来恶 劣天气可能带来的影响, 做好预防和防 范措施, 减少对人们日常生活的影响 ${ }^{[5]}$ 。

\section{3提高台站预警服务}

对于气象服务来说, 市县气象局始 终是气象服务中的重要部门, 重要负责 提供气象服务、保护农民生活、防灾减 灾、促进农业生产。在多方努力之下, 气象台也新增了许多预报项目, 包括舒 适指数播报、紫外线指数播报等, 同时推 出气象预报制作系统, 加大了语音合成 项目。随着科学技术的发展, 气象行业也 在积极引进先进技术, 离子监测数据就
是其中一项, 在预报软件中的应用较为 广泛, 取得的效果也十分良好, 为人们提 供了更加优质的服务 ${ }^{[6]}$ 。

2. 4 加强人才队伍建设

天气预报工作和工作人员的专业能 力和实际操作水品有着直接关系, 在现 代预报技术的辅助下, 建立高素质高质 量的预报人才队伍十分重要, 这也是提 高天气预报准确性的重点和关键。可以 定期安排天气预报相关专业知识的培训, 加强岗位培训, 建立轮换机制, 并对轮换 机制进行规范, 使其具有科学合理性。同 时, 提高对综合业务岗位锻炼、培训和实 习的重视。结合具体天气预报例子, 尤其 是重大灾害性天气过程实例, 在讲解天 气预报技术时也可以提高业务人员对本 工作的重视程度, 帮助预报人员提高自 身专业能力, 扩展知识储备范围。还可以 通过培训发现骨干人员和有潜力的工作 人员, 促进人才队伍建设的同时提升了 员工的整体素质 ${ }^{[7]}$ 。

2.5 提高数据信息分析的先进性

先进技术在天气预报行业的应用十 分广泛, 目前气象数据分析系统也得到 了引进, 利用计算机技术对观测数据进 行分析, 同时对观测状况进行整理和研 究, 可以有效提高观测结果的准确性。和 传统观测方法相比, 观测系统的自动化 进程和创新更具先进性, 可以不断反馈 观测数据信息, 计算机技术可以更好的 统计和分析这些数据信息, 提高其利用 率, 进而充分发挥其作用和价值。除此之 外, 根据数据分析体系的分析结果, 储存
和利用观测数据信息, 为后续工作提供 数据基础, 也可以为员工提供参考资料。

\section{3 结束语}

天气预报是各行各业发展的根本保 证, 现阶段天气预报缺乏一定的准确性, 要想提高其精准性, 就需要提高观测数 据信息的可靠性和完整性, 积极引进先 进观测方法和技术, 天气预报准确率可 以得到有效提高。希望本文的研究对天 气预报工作的进一步发展具有积极作用, 保证天气预报精准性的同时也可以推动 气象行业的进步, 进而为国民经济发展 奠定良好基础。

\section{[参考文献]}

[1]于嘉媛.试分析影响天气预报准确 率的因素[J].科学与信息化,2019,(18):198.

[2]间亮,李作平, 张德惠. 影响天气 预报准确性的因素及对策[J].农业技术 与装备,2019,349(01):75+78.

[3] 乌吉斯古林, 金花, 段启勇.关于 气象预报准确率的因素分析 [ J ]. 农民致 富之友,2014,(19):60-61.

[4]周德伟,张雷,周立馥,等.简析影 响天气预报准确率的因素及其措施 [J]. 名城绘,2018,(007):675.

[5]尤敏,钟莉.影响气象预报准确率 的因素[J].江西农业,2017,(15):49.

[6]吴䑣,罗云凯,李丹,等.关于提高 天气预报准确率的思考及建议 [ J ]. 农村 经济与科技,2017,028(021):245-246。

[7]孙立谦,宋鹤群.关于气象预报准确 率的因素分析[J].中国西部,2017,(8):140. 